\title{
Faktor-faktor kesiapsiagaan bencana terintegrasi pengetahuan prekursor gempa bumi pada mahasiswa Pendidikan IPA
}

\author{
Muhyiatul Fadilah*, Enok Maryani**, Riandi*, Anna Permanasari* \\ * Program Studi Doktor Pendidikan IPA Sekolah Pascasarjana Universitas Pendidikan Indonesia, \\ Indonesia \\ ** Program Studi Pendidikan Geografi Sekolah Pascasarjana Universitas Pendidikan Indonesia, \\ Indonesia
}

ARTICLES INFO

Profil Articles:

Sent: $12-6-2020$

Approved: 4-11-2020

Published: 30-1-2021

\section{Key words:}

Kesiapsiagaan; jenis kelamin; daerah asal; penanda gempa bumi; mahasiswa

\section{ABSTRACT}

Preparedness is the main competency that must be possessed by disaster-prone communities, including students. Preparedness is built on knowledge. Previous research shows the level of student preparedness varies greatly, but there is no explanation yet about the relationship of knowledge and other factors that affect student preparedness. In addition, preparedness measures have not yet examined the component of disaster markers or precursors. This research was conducted to describe the factors associated with the level of student preparedness. The study population was science education students and the research sample was determined purposively, so that 104 science students took IPBA courses as samples. Research is descriptive research. Data collection was carried out through a TPPG preparedness questionnaire and an earthquake precursor knowledge test. In addition, secondary data in the form of UTS values are also used that represent basic earthly knowledge that is relevant to earthquake preparedness. The results showed that 1) TPPG preparedness for students was in the moderate / sufficient category, 2) preparedness was influenced by the area of origin of students and was not influenced by gender and earth knowledge, 3) students' knowledge of earthquake markers was very low.

Kesiapsiagaan merupakan kompetensi utama yang harus dimiliki oleh masyarakat rawan bencana, termasuk pada mahasiswa. Kesiapsiagaan dibangun oleh pengetahuan. Penelitian terdahulu menunjukkan level kesiapsiagaan mahasiswa sangat bervariasi, namun belum terdapat penjelasan tentang hubungan pengetahuan dan faktor-faktor lain yang memengaruhi kesiapsiagaan mahasiswa. Selain itu, pengukuran kesiapsiagaan belum mengkaji komponen penanda bencana atau prekursor. Penelitian ini dilakukan untuk mendeskripsikan faktor-faktor yang berhubungan dengan level kesiapsiagaan mahasiswa. Populasi penelitian adalah mahasiwa pendidikan IPA dan penentuan sampel penelitian dilakukan secara purposive, sehingga sebanyak 104 mahasiwa pendidikan IPA yang mengambil matakuliah IPBA ditetapkan sebagai sampel. Penelitian merupakan penelitian deksriptif. Pengumpulan data dilakukan melalui angket kesiapsiagaan TPPG dan tes pengetahuan prekursor gempabumi. Selain itu, juga digunakan data sekunder berupa nilai Ujian Tengah Semester yang merespresentasikan pengetahuan dasar kebumian yang relevan dengan kesiapsiagaan gempabumi. Teknik analisis data yang digunakan adalah Uji Korelasi Kendalls' tau dan kuantitatif-deskriptif. Hasil penelitian menunjukkan bahwa 1) kesiapsiagaan TPPG pada mahasiswa berada pada kategori sedang/cukup, 2) kesiapsiagaan dipengaruhi oleh daerah asal mahasiswa dan tidak dipengaruhi oleh jenis kelamin dan pengetahuan kebumian, 3) pengetahuan mahasiswa tentang penanda gempabumi sangat rendah. Dapat disimpulkan bahwa daerah asal memengaruhi kesiapsiagaan TPPG mahasiswa pendidikan IPA.

This is an open access article under the CC-BY-SA license 
Jurnal Pendidikan Geografi:

Kajian, Teori, dan Praktik dalam Bidang Pendidikan dan Ilmu Geografi

Volume 26, Nomor 1, Januari 2021, Hal 1-14

\section{Correspondent Author:}

Muhyiatul Fadilah

Program Studi Doktor Pendidikan IPA Sekolah Pasca Sarjana

Universitas Pendidikan Indonesia

J1. Dr. Setiabudhi No.229, Cidadap, Isola, Sukasari, Isola, Kec. Sukasari, Kota Bandung, Jawa

Barat 40154

E-mail: muhyifadilah@upi.edu

\section{PENDAHULUAN}

Indonesia merupakan negara rawan bencana geologi antara lain banjir, gempa bumi, longsor, tsunami, gunung meletus, dan siklon (Tjandra, 2018). Data rekaman kegempaan di BMKG ataupun data global menunjukkan adanya lompatan aktivitas kegempaan secara signifikan, terutama selama 2 tahun terakhir. Sebagai contoh gempabumi di Indonesia rata-rata terjadi 5.000 kali dalam satu tahun, tetapi sejak tahun 2017 telah meningkat menjadi 7.000 kali, bahkan melompat hingga 11.920 kali di tahun 2018 (BMKG, 2019).

Direktorat Vulkanologi dan Mitigasi Bencana Geologi, Departemen Energi Dan Sumber Daya Mineral menyatakan provinsi yang terletak di sepanjang pantai barat Pulau Sumatera hingga Pulau Sulawesi, berjumlah sekitar 28 wilayah. Sumatera Barat menjadi daerah paling rawan bencana gempa bumi dan tsunami, terutama pada tujuh kabupaten/ kota, termasuk Kota Padang/Kabupaten Padang Pariaman. Perkembangan zona bencana seismik baru menginformasikan pesisir Barat Sumatera berdampingan dengan setidaknya 3 zona subduksi megathrust terdekat, yaitu Batu, Mentawai-Siberut, dan Mentawai-Pagai (Irsyam dkk., 2017). Akibatnya, masyarakat sumatera Barat berada dalam ancaman resiko seismik, yaitu berpeluang menghadapi konsekuensi yang tidak diinginkan akibat terjadinya gempa bumi (Bommer, Crowley, \& Pinho, 2015) sehingga masyarakat Sumatera Barat dikategorikan sebagai masyarakat rawan bencana.

Kesiapsiagaan merupakan kemampuan utama yang harus dimiliki oleh masyarakat rawan bencana. Kesiapsiagaan dipengaruhi oleh banyak faktor, salah satunya adalah faktor pengetahuan atau kognitif (Brown, Haun, \& Peterson, 2014). Pengetahuan merupakan aspek mental yang mendasari sikap dan tindakan. Menurut (Hidayati, Widyatun, Triono \& Kusumawati, 2011), pengetahuan tentang bencana merupakan faktor utama dan menjadi kunci untuk kesiapsiagaan terhadap bencana. Hasil studi UNESCO menunjukkan bahwa tingkat resiko semakin tinggi karena sebagian besar masyarakat daerah rawan bencana memiliki pengetahuan rendah yang berhubungan dengan rendahnya kesiapan bencana (disaster preparedness) (Adiyoso \& Kanegae, 2013; Kohn dkk., 2012) . Pendapat ini sejalan dengan hasil penelitian Brown dkk., (2014) yang mengemukakan rendahnya pendidikan dan rendahnya literasi merupakan faktor yang berpengaruh negatif untuk keamanan selama dan setelah terjadi bencana, selain kondisi fisik, isolasi sosial, dan keterbatasan sumber daya finansial. Upaya yang dapat dilakukan adalah meminimalisir dampak bencana melalui peningkatan literasi informasi bencana dan kesiapsiagaan bencana (Marlyono, 2016).

Perguruan tinggi berperan penting dalam peningkatan pendidikan keselamatan (educational safety) bencana alam, termasuk gempabumi (Baytiyeh \& Naja, 2014). Beberapa peneliti mendekripsikan kesiapsiagaan bencana mahasiswa dan peran pengetahuan dalam kesiapsiagaan. (Kurniawati \& Suwito, 2019) menemukan sikap kesiapsiagaan mahasiswa pendidikan Geografi dalam menghadapi bencana berada pada kategori sangat tinggi. (Sajidah, Hasmunir, \& Abdi, 2017) menemukan bahwa kesiapsiagaan gempabumi dan tsunami pada mahasiswa program studi Geografi FKIP 
Jurnal Pendidikan Geografi:

Kajian, Teori, dan Praktik dalam Bidang Pendidikan dan Ilmu Geografi

Volume 25, Nomor 2, Jun 2020, Hal 88-101

Unsyiah memiliki hubungan yang positif dan signifikan dengan nilai mata kuliah Geologi Umum dan Mitigasi Bencana. Hasil penelitian berbeda ditemukan dalam penelitian (Fadhil, 2019), bahwa pengetahuan tidak memiliki hubungan siginifikan dengan aspek sikap dan tindakan kesiapsiagaan bencana alam pada mahasiswa Program Studi Profesi Dokter Fakultas Kedokteran Universitas Andalas.

Sebagian besar penelitian tentang kesiapsiagaan gempabumi mahasiswa berfokus pada mahasiswa bidang ilmu geografi, keperawatan dan kedokteran, antara lain dilakukan oleh (Novarita, 2019), (Novarita, 2019) (Novarita, 2019) (Sajidah dkk., 2017) (Iryanthony, 2015) (Kurniawati \& Suwito, 2019), (Rafelito \& Triyatno, 2019), (Addiarto \& Yunita, 2019), (Hariyanto \& Kurniawati, 2019), (Rizqillah, 2019), dan (Ilham dkk., 2016). Penelitian yang melibatkan mahasiswa bidang keilmuan sains sangat terbatas jumlahnya termasuk mahasiswa program studi pendidikan IPA UNP. Universitas Negeri Padang (UNP) merupakan perguruan tinggi yang berada di daerah rawan gempabumi Sumatera Barat dan termasuk dalam kawazan zona paling beresiko tsunami karena berlokasi di pesisir pantai kota Padang. UNISDR 2001 dalam (Coppola, 2015) menekankan pentingnya kontribusi masyarakat saintifik, termasuk mahasiswa UNP, dalam upaya reduksi dampak bencana.

Pengukuran kesiapsiagaan mahasiswa UNP telah pernah dilakukan oleh (Rafelito \& Triyatno, 2019). Hasil penelitian menunjukkan bahwa parameter pengetahuan kesiapsiagaan bencana gempabumi dan tsunami mahasiswa UNP dari semua fakultas dikategorikan tinggi dan parameter rencana tanggap darurat dan sistem peringatan dini mencapai kategori sedang. Temuan menarik dari penelitian tersebut adalah mahasiswa Fakultas MIPA memiliki level pengetahuan berada pada kriteria yang lebih rendah dibanding mahasiswa dari fakultas lainnya. Namun, peneliti tersebut tidak mengemukakan faktor-faktor spesifik yang berhubungan dengan lebih rendahnya kesiapsiagaan mahasiswa FMIPA. Penelitian relevan dilakukan oleh (Fadilah, Permanasari, Riandi, \& Maryani, 2020) namun memfokuskan pada literasi bencana, dan menemukan bahwa literasi bencana mahasiswa FMIPA mencapai kategori tinggi pada aspek sikap dan tindakan, tetapi berada pada kategori sangat rendah untuk aspek pengetahuan sehingga disimpulkan bahwa mahasiswa termasuk "unaware" sebagai "scientist" dan "educated" sebagai "citizen". Ada tiga alasan yang menjelaskan potensi kontribusi mahasiswa pendidikan IPA UNP dalam membangun kesiapsiagaan gempabumi. Pertama, mahasiswa pendidikan IPA mempelajari bidang keilmuan IPA yang relevan dengan gempabumi seperti Ilmu Pengetahuan Bumi dan Antariksa (IPBA), kedua mahasiswa akan mendifusikan pengetahuan gempabumi dan kesiapsiagaan gempabumi bagi siswa-siswa SD, SMP dan SMA dan ketiga, mahasiswa berpotensi terlibat dalam program-program pendidikan kebencanaan dalam masyarakat, dan mampu memberikan intervensi yang tepat pada saat sebelum, saat dan sesudah gempabumi terjadi.

Penelitian terdahulu umumnya mengkaji tentang karakteristik bencana dan pengetahuan tentang cara penanggulangan bencana. Sementara pendekatan manajemen bencana saat ini menekankan pada pencegahan dan minimilisasi dampak/resiko bencana, salah satunya adalah pengetahun pengenalan gejala bencana. Pengetahuan mengenai gejala bencana sekitar merupakan hal penting dalam kesiapsiagaan masyarakat (Abidin, 2015 dalam (Fauzi, Hidayati, Subagyo, Sukini, \& Latif, 2017)). Sebagai contoh, minimnya pengetahuan masyarakat Aceh dan Simelue terhadap makna dari fenomena surutnya air laut sebelum gempa dan tsunami 2006, merupakan salah satu bukti bahwa rendahnya pengetahuan tentang gejala alam penanda gempa bumi menyebabkan tingginya resiko dampak bencana. 
Jurnal Pendidikan Geografi:

Kajian, Teori, dan Praktik dalam Bidang Pendidikan dan Ilmu Geografi

Volume 25, Nomor 2, Jun 2020, Hal 88-101

Tabel 1. Anomali Fenomena Alam dan Perilaku Hewan

\begin{tabular}{lll}
\hline No & \multicolumn{1}{c}{ Prekursor Gempa bumi } & \multicolumn{1}{c}{ Peneliti (Tahun) } \\
\hline 1 & Anomali Radon & (Deb, Gazi, Ghosh, Chowdhury, \& Barman, 2018);(Oh \& Kim, 2015) \\
2 & Anomali di ionosfer & (Sunardi, Muslim, \& Pakpahan, 2016); \\
3 & Anomali temperature & (Saraf \& Choudhury, 2004);(Saraf \& Choudhury, 2005) \\
4 & Anomali elektromagnet & (Song, Hattori, Zhang, \& Sanaka, 2020)., (Ahadi, Puspito, \& Ibrahim, \\
5 & Awan gempa & (Daneshvar, Tavousi, \& Khosravi, 2014); (Morozova, 2012) \\
6 & Anomali perilaku Burung & (Zollinger \& Brumm, 2015) \\
7 & Anjing \& kucing & (Yamauchi, Uchiyama, Ohtani, \& Ohta, 2014), 2014 \\
8 & Sapi & (Fidani, Freund, \& Grant, 2014) \\
9 & Mencit & (Yokoi, Ikeya, Yagi, \& Nagai, 2003), \\
\hline
\end{tabular}

Sumber: Hasil penelusuran peneliti, 2020

Pengetahuan fenomena penanda suatu bencana dikenal dengan istilah prekursor. Dalam kajian sains kebencanaan, gempabumi merupakan bencana alam yang didahului oleh kemunculan sejumlah prekursor, yang dapat dibedakan menjadi prekursor mekanik, elektromagnetik dan prekursor anomali makro (Hayakawa, 2013). Kemunculan prekursor gempabumi diindikasikan oleh anomali peristiwa alam dan perilaku hewan. Data-data anomali alami dan hewani sebelum gempabumi di sejumlah lokasi gempabumi terbukti memberitahu terjadinya gempabumi setelah beberapa hari kemunculan anomali. Beberapa contoh anomali alam dan perilaku hewan sebelum gempabumi yang pernah diteliti dan dipublikasikan disajikan pada Tabel 1.

Pengetahuan prekursor merupakan komponen yang potensial dan tidak terpisahkan dari parameter pengetahuan kesiapsiagaan bencana dan berhubungan dengan parameter rencana tanggap darurat dan sistem peringatan dini. Melihat perkembangan pengetahuan prekursor gempabumi dan perannya dalam kesiapsiagaan gempabumi, maka peneliti tertarik untuk mengkaji pengukuran kesiapsiagaan gempabumi yang mengintegrasikan pengetahuan prekursor ke dalam parameter pengetahuan, rencana tanggap darurat, dan sistem peringatan dini mahasiswa program sudi pendidikan IPA UNP.

Artikel ini bertujuan untuk mendeskripsikan faktor-faktor yang menentukan kesiapsiagaan terintegrasi pengetahuan penanda gempabumi (berikutnya disingkat Kesiapsiagaan TPPG). Penelitian terdahulu menyatakan bahwa kesiapsiagaan terhadap bencana dipengaruhi oleh jenis kelamin karena perbedaan jenis kelamin mungkin membentuk persepsi yang berbeda sehingga memengaruhi sikap dan pengetahuan yang berbeda juga antara laki-laki dan perempuan. Hal ini memang menjadi perdebatan apakah laki-laki dan perempuan berbeda dalam bagaimana jalan mereka membuat keputusan etis dan kognitif (Normadewi \& Arifin, 2012). Hasil penelitian (Havwina, Maryani, \& Nandi, 2017) menunjukkan bahwa pengalaman bencana memengaruhi kesiapsiagaan baik secara langsung atau tidak langsung. Dalam hal ini, karakteristik daerah asal diduga juga berhubungan dengan kesiapsiagaan bencana. (Sampurno, Sari, \& Wijaya, 2015) menemukan terdapat pengaruh positif dan signifikan pengetahuan kebencanaan dan sikap masyarakat terhadap kesiapsiagaan menghadapi bencana longsor. Peneliti mengasumsikan bahwa pengetahuan termasuk faktor yang memengaruhi kesiapsiagaan bencana gempabumi. Oleh sebab itu, rumusan masalah dalam penelitian ini adalah: 1) Bagaimana jenis kelamin, daerah asal, dan pengetahuan kebumian 
Jurnal Pendidikan Geografi:

Kajian, Teori, dan Praktik dalam Bidang Pendidikan dan Ilmu Geografi

Volume 25, Nomor 2, Jun 2020, Hal 88-101

memengaruhi kesiapsiagaan TPPG pada mahasiswa pendidikan IPA? 2) Bagaimana pengetahuan penanda gempabumi dan potensi integrasi pengetahuan penanda gempabumi untuk membangun kesiapsiagaan mahasiswa pendidikan IPA?

METODE

Penelitian ini merupakan penelitian deskriptif. Populasi penelitian adalah mahasiswa pendidikan IPA Universitas Negeri Padang dan sampel penelitian adalah mahasiswa pendidikan IPA TM 2018 yang sedang mengikuti matakuliah Ilmu Pengetahuan Bumi dan Antariksa (IPBA). Penentuan sampel menggunakan teknik purposive sampling melibatkan 104 mahasiswa (berdasarkan jumlah angket yang diisi secara lengkap). Pemilihan populasi dan sampel dilakukan berdasarkan pertimbangan bahwa mahasiswa IPA tersebut telah mengkaji struktur bumi beserta proses yang terjadi di litosfer, termasuk becana gempa bumi, sehingga dapat diasumsikan memahami bencana alam gempabumi dari persepektif ilmu sains. Penelitian dilaksanakan pada bulan Oktober sampai Desember 2019. Pengambilan data menggunakan teknik survey dengan dua instrumen, yaitu angket kesiapsiagaan gempabumi (dimodifikasi dari instrumen survey kesiapsiagaan bencana (LIPI_UNESCO/ISDR, 2006) dan tes pengetahuan prekursor gempabumi alami dan hewani yang dikembangkan oleh peneliti. Angket kesiapsiagaan bencana terdiri dari 4 indikator, setiap indikator terdiri dari sejumlah pertanyaan yang mewakili 4 paramater kesiapsiagaan bagi mahasiswa calon pendidik. Parameter tersebut adalah pengetahuan dan sikap, rencana tanggap darurat, sistem peringatan dini, dan mobilisasi sumber daya, yang telah ditetapkan sebagai parameter standar untuk mengukur kesiapsiagaan bencana masyarakat. Selain itu, peneliti menggunakan data sekunder berupa nilai Ujian Tengah Semester (UTS) yang merepresentasikan pengetahuan dasar kebumian, meliputi litosfer, atmosfer dan hidrosfer. Analisis data yang digunakan terdiri dari 2 yaitu teknik deskriptif kuantitatif dan statistik inferensial. Statistik deskriptif berbentuk persentase dengan visualisasi diagram dan tabel digunakan untuk mendeskripsikan jumlah, tingkat atau perbandingan variabel.

Rumusnya adalah $\boldsymbol{P}(\%)=\frac{\text { Skor }}{{ }^{\text {Skor Maksimal }}} \boldsymbol{x} \mathbf{1 0 0}$, dimana $\mathrm{P}$ adalah Persentase. Statistik inferensial teknik korelasi Kendall tau digunakan untuk mengetahui terdapat atau tidak adanya hubungan antara satu variabel dengan variabel lainnya.

Formula Kendall Tau adalah $T=\frac{2 S}{\boldsymbol{N ( N - 1 )}}$, dimana $T$ adalah nilai koefisien Kendall Tau, S adalah pembilang yang berasal dari jumlah konkordansi dan disonkordasi jenjang secara keseluruhan, $\mathrm{N}$ adalah Jumlah sampel, dan 1, 2 merupakan konstanta.

\section{HASIL DAN PEMBAHASAN}

Tingkat kesiapsiagaan individu terhadap bencana dapat dikelompokkan menjadi tiga, yaitu tinggi (nilai indeks 80-100), sedang (nilai indeks 60-79) dan rendah (nilai indeks < 60) (Hidayati, 2011). Nilai rata-rata pencapaian Kesiapsiagaan TPPG pada mahasiswa pendidikan IPA adalah 73.65 , termasuk pada kategori sedang, yang diitunjukkan oleh hampir sebagian besar (62.5\%) mahasiswa. Hanya 10\% yang memiliki Kesiapsiagaan TPPG level rendah. Perbandingan presentase level Kesiapsiagaan TPPG mahasiswa ditampilkan pada diagram Gambar 1.

Untuk mengetahui faktor-faktor yang memengaruhi level Kesiapsiagaan TPPG, peneliti melakukan uji korelasi antara beberapa faktor yang diduga terkait, ditampilkan 
Jurnal Pendidikan Geografi:

Kajian, Teori, dan Praktik dalam Bidang Pendidikan dan Ilmu Geografi

Volume 25, Nomor 2, Jun 2020, Hal 88-101

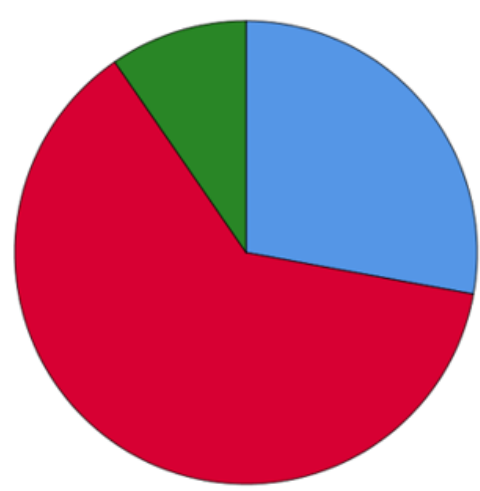

\begin{tabular}{|l|l|}
\hline & Tinggi (62,5\%) \\
\hline & Sedang $(27,5 \%)$ \\
\hline & Rendah $(10 \%)$ \\
\hline
\end{tabular}

Gambar 1. Perbandingan Persentase Level Kesiapsiagaan TPPG Mahasiswa (Sumber: Hasil pengolahan data, 2020)

Tabel 2. Hasil analisis kuantitatif dengan teknik Korelasi Kendall tau

\begin{tabular}{|c|c|c|c|c|c|}
\hline Variabel & Jenis Kelamin & Daerah Asal & Kesiapsiagaan & $\begin{array}{c}\text { Pengetahuan } \\
\text { Kebumian }\end{array}$ & $\begin{array}{c}\text { Pengetahuan } \\
\text { Prekursor }\end{array}$ \\
\hline Jenis Kelamin & 1.000 & .141 & -.018 & .024 & -.053 \\
\hline Daerah Asal & .141 & 1.000 & $.221^{* *}$ & -.007 & -.084 \\
\hline Kesiapsiagaan & -.018 & $.221^{* *}$ & 1.000 & .036 & .076 \\
\hline Pengetahuan Kebumian & .024 & -.007 & .036 & 1.000 & .044 \\
\hline Pengetahuan Prekursor & -.053 & -.084 & .076 & .044 & 1.000 \\
\hline
\end{tabular}

(Sumber: Hasil pengolahan data, 2020)

pada Tabel 2. Hasil uji menunjukkan jenis kelamin dan pengetahuan kebumian tidak menunjukkan pengaruh signifikan terhadap Kesiapsiagaan TPPG yang telah dimiliki oleh mahasiswa pendidikan IPA. Faktor yang telah memengaruhi Kesiapsiagaan TPPG adalah faktor daerah asal yang ditunjukkan oleh koefisien korelasi sebesar 0.221.

\section{Jenis Kelamin dan Kesiapsiagaan TPPG}

Rasio jumlah mahasiswa laki-laki dan perempuan adalah $6.4 \%$ berbanding 93.6\%. Nilai rata-rata kesiapsiagaan, pengetahuan dasar kebumian, dan pengetahuan penanda gempa bumi pada mahasiswa laki-laki dan perempuan disajikan pada Tabel 3. Hasil pengujian secara statistik menunjukkan jenis kelamin tidak berpengaruh terhadap Kesiapsiagaan TPPG yang telah dimiliki oleh mahasiswa pendidikan IPA. Jenis kelamin merupakan salah satu isu penting untuk yang dipertimbangkan sebab Ashraf \& Azad (2015) menemukan bahwa perempuan, terutama dari daerah pesisir, menghadapi lebih banyak kendala dalam mitigasi bencana karena sangat sedikit dilibatkan dalam aktivitas perencanaan kesiapsiagaan bencana. Kendala tersebut berasosiasi dengan beragamnya konstruksi sosial dan kultural perempuan antara satu komunitas dengan komunitas lainnya, mencakup peran, tanggungjawab, akses ke sumber daya, hambatan, kesempatan, kebutuhan, persepsi dan pandangan. 
Jurnal Pendidikan Geografi:

Kajian, Teori, dan Praktik dalam Bidang Pendidikan dan Ilmu Geografi

Volume 25, Nomor 2, Jun 2020, Hal 88-101

Tabel 3. Nilai rata-rata kesiapsiagaan, pengetahuan kebumian dan pengetahuan penanda gempa bumi pada mahasiswa Pendidikan IPA berdasarkan jenis kelamin

\begin{tabular}{lcc}
\hline \multicolumn{1}{c}{ Aspek } & Laki-laki & Perempuan \\
\hline Kesiapsiagaan & 73.94 & 73.36 \\
Pengetahuan kebumian & 72.67 & 73.78 \\
Pengetahuan penanda gempa bumi & 29.58 & 26.43 \\
\hline
\end{tabular}

(Sumber: Hasil pengolahan data, 2020)

Tidak adanya pengaruh jenis kelamin mungkin dapat disebabkan oleh proporsi mahasiswa laki-laki yang jauh lebih sedikit dibanding mahasiswa perempuan. Namun, permasalahan proporsi jenis kelamin dan perempuan merupakan realitas yang terdapat pada hampir semua kelompok belajar di Indonesia. Hal ini disebabkan oleh kecenderungan peningkatan Angka Partisipasi Murni (APM) perempuan terhadap lakilaki. Pada jenjang perguruan tinggi rasio APM perguruan tinggi perempuan telah meningkat dari rata-rata 85,73 persen (1992-2002) menjadi 97,24 persen (2003-2006) (Rahayu \& Wigna, 2011). Peningkatan ini diindikasikan oleh cenderung lebih sedikitnya jumlah siswa atau mahasiswa pada sebagaian besar sekolah atau universitas, kecuali pada bidang peminatan tertentu. Penelitian (Muafiroh, Suroto, \& Ekawati, 2017) juga menemukan tidak adanya hubungan antara jenis kelamin dengan upaya kesiapsiagaan tanggap darurat keselamatan dan kesehatan kerja (K3) di Laboratorium Kimia pada kelompok mahasiswa dengan rasio jenis kelamin 72,86 \% perempuan dan 27,14\% lakilaki. Sebaliknya, (Addiarto \& Yunita, 2019) menemukan bahwa terjadi peningkatan kesiapsiagaan pada mahasiswa Keperawatan setelah menggunakan metode tertentu, dimana hanya $25 \%$ mahasiswa yang berjenis kelamin laki-laki. Dengan demikian, jenis kelamin laki-laki tetap berkemungkinan memberikan atau tidak memberikan pengaruh, hubungan, atau kontribusi terhadap suatu variabel efek yang diukur pada kondisi real yang sebenarnya.

Kecenderungan pengaruh jenis kelamin terlihat pada pengetahuan dasar kebumian dan pengetahuan penanda gempa bumi, dimana koefesien korelasi yang ditampilkan lebih besar dibanding pengaruhnya terhadap kesiapsiagaan. Hal ini diduga karena laki-laki memiliki kemampuan yang lebih baik dalam memahami materi yang memiliki karakteristik spasial ruang seperti pada materi kebumian materi dan kemunculan penanda gempa bumi. (Purborini \& Hastari, 2019) menemukan bahwa siswa laki-laki memiliki kemampuan penyelesaian masalah yang lebih baik menggunakan pengimajinasian dibanding siswa perempuan pada materi bangun ruang, tetapi perlu penelitian lanjut pengaruh jenis kelamin dalam memecahkan permasalahan kontekstual seperti dalam kondisi bencana gempa bumi.

\section{Daerah Asal dan Kesiapsiagaan TPPG}

Daerah asal merupakan lingkungan dimana individu tinggal dalam durasi relatif lama. Dalam kajian penanggulangan bencana, daerah tinggal dikarakterisasi menjadi daerah rawan bencana jika memiliki analisis potensi resiko, bahaya dan ancaman gempa bumi yang tinggi. Lebih spesifik, daerah rawan bencana dapat dibedakan lagi dalam sistem zonasi merah, kuning dan hijau berdasarkan gradasi tingkat bahaya dan kebutuhan pemetaan evakuasi. 
Jurnal Pendidikan Geografi:

Kajian, Teori, dan Praktik dalam Bidang Pendidikan dan Ilmu Geografi

Volume 25, Nomor 2, Jun 2020, Hal 88-101

Sumatera Barat telah dikategorisasi menjadi provinsi rawan gempa bumi. Perkembangan fenomena kebencanaan gempa bumi yang diikuti dengan perkembangan persepsi bahwa daerah dataran rendah dan dataran tinggi memiliki tingkat resiko yang berbeda, dimana dataran rendah cenderung lebih diwaspadai karena dapat terjangkau jika terjadi gelombang tsunami sebagai bencana ikutan dari gempa bumi. Dengan demikian, mahasiswa yang berasal dari daerah dataran rendah diperkirakan memiliki kesiapsiagaan lebih baik dibanding mahasiswa yang tinggal di dataran tinggi, apalagi mahasiswa yang berasal dari daerah di luar daerah rawan bencana. Hasil survei menginformasikan bahwa jumlah mahasiswa yang berasal dari dataran tinggi Sumatera Barat lebih banyak daripada daerah dataran rendah Sumatera Barat dan daerah luar Sumatera Barat. Persentase jumlah diilustrasikan dalam diagram pada Gambar 2.

Hasil uji korelasi pada Tabel 2 menunjukkan bahwa terdapat korelasi signifikan antara daerah asal dan Kesiapsiagaan TPPG pada mahasiswa pendidikan IPA, dengan nilai koefisien korelasi sebesar 0.221. Perbandingan nilai kesiapsiagaan antara tiga kelompok mahasiswa berdasarkan kategori daerah asal ditampilkan pada Tabel 4 . Mahasiswa yang berasal dari dataran rendah memiliki level kesiapsiagaan paling tinggi, sebaliknya mahasiswa yang berasal dari luar Sumatera Barat memiliki level kesiapsiagaan paling rendah. Hal ini mengindikasikan bahwa faktor keterpaparan dalam lingkungan atau konteks bencana berpengaruh terhadap pengetahuan Kesiapsiagaan TPPG karena peluang mahasiswa memiliki pengalaman gempa bumi dan sosialisasi tentang penanggulangan gempa bumi lebih besar. Hal ini sesuai dengan penelitian (Havwina dkk., 2017) bahwa pengalaman berhubungan dengan kesiapsiagaan siswa SMA di Banda Aceh. Hasil serupa ditemukan oleh (Rachmalia, Hatthakit, \& Chaowalit, 2011) dimana kesiapsiagaan masyarakat di daerah terkena bencana (affected area) lebih tinggi dibanding yang berasal dari non affected area.

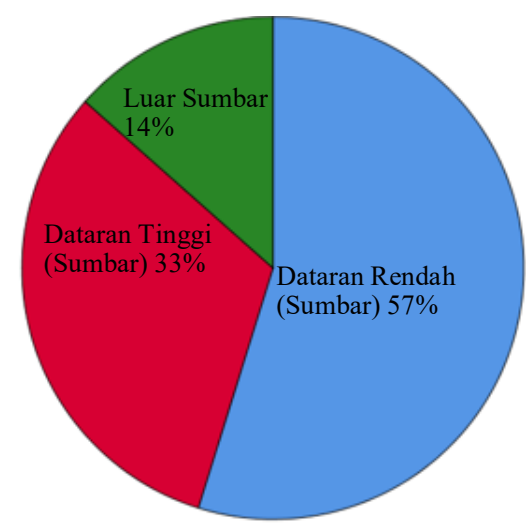

Gambar 2. Perbandingan proporsi daerah asal mahasiswa

(Sumber: Hasil pengolahan data, 2020)

Tabel 4. Nilai Kesiapsiagaan, pengetahuan kebumian dan pengetahuan penanda gempa bumi (berdasarkan daerah asal)

\begin{tabular}{lccc}
\hline Indikator & $\begin{array}{c}\text { Dataran Rendah } \\
\text { Sumbar }\end{array}$ & $\begin{array}{c}\text { Dataran Tinggi } \\
\text { Sumbar }\end{array}$ & Luar Sumbar \\
\hline Kesiapsiagaan & 75.76 & 71.98 & 67.12 \\
Pengetahuan kebumian & 73.75 & 73.72 & 73.5 \\
Pengetahuan penanda & 27.19 & 26.36 & 24.82 \\
\hline
\end{tabular}


Jurnal Pendidikan Geografi:

Kajian, Teori, dan Praktik dalam Bidang Pendidikan dan Ilmu Geografi

Volume 25, Nomor 2, Jun 2020, Hal 88-101

\section{Pengetahuan Kebumian}

Pengetahuan dasar kebumian meliputi pengetahuan tentang litosfer, atmosfer dan hidrosfer. Pengetahuan dasar kebumian memuat penjelasan tentang karakteristik struktur bumi, penyebab dan mekanisme gempa bumi serta proses-proses fisika di atmosfer dan hidrosfer yang terpengaruh baik sebelum (prekursor) dan setelah gempa bumi. Pencapaian tingkat pengetahuan dasar kebumian pada mahasiswa pendidikan IPA mencapai nilai rata-rata 73.73\%, termasuk pada kategori cukup/sedang seperti yang ditampilkan pada Tabel 3. Hasil uji korelasi menunjukkan bahwa pengetahuan kebumian yang telah dimiliki dan dipelajari dalam matakuliah relevan seperti IPBA tidak menunjukkan pengaruh terhadap kesiapsiagaan TPPG mahasiswa pendidikan IPA. Dengan kata lain, pengetahuan tentang pengenalan sifat fisik kebumian, belum memberikan kontribusi terhadap kesiapsiagaan TPPG mahasiswa pendidikan IPA.

Pengetahuan memiliki peran penting dalam membentuk sikap mental dan tindakan individu. Pengetahuan yang tepat akan memberikan dasar bersikap dan bertindak logis, penuh pertimbangan dan matang. Mahasiswa pendidikan IPA dibekali dengan bahan kajian kebumian dalam matakuliah Ilmu Pengetahuan Bumi dan Antariksa, meliputi materi tentang tentang litosfer, atmosfer, dan hidrosfer. Ketiga topik tersebut adalah topik substansial untuk dikaitkan dengan pengetahuan kebencanaan. Dengan demikian, diperlukan peningkatan pengetahuan dasar tentang litosfer, atmosfer, dan hidrosfer yang relevan dan terintegrasi dengan pengetahuan kebencanaan serta kesiapsiagaan gempa bumi pada mahasiswa pendidikan IPA.

\section{Pengetahuan Penanda Gempa Bumi Mahasiswa Pendidikan IPA}

Salah satu bentuk pengetahuan yang penting untuk membangun kesiapsiagaan bencana adalah pengetahuan tentang penanda atau prekursor bencana. Tren pentingnya pengetahuan prekursor gempa bumi telah berkembang di negara-negara rawan bencana gempa bumi seperti Jepang dan China dan telah menjadi bidang riset khusus. Secara umum, prekursor terdiri dari 3 jenis, yaitu prekursor mekanik, prekursor elektromagnetik dan prekursor makhluk hidup (hewan). Hasil penelitian para pakar dalam bidang tersebut telah menunjukkan prekursor merupakan bagian penting dalam prediksi gempa bumi dan telah dipublikasi secara internasional.

Pengetahuan tentang prekursor gempa bumi pada mahasiswa pendidikan IPA termasuk mencapai nilai rata-rata 26.12 berada pada kategori sangat rendah. Ada 2 kelompok besar prekursor gempa bumi, yaitu prekursor mikro yang terdiri atas anomali (keanehan) fenomena alami fisika dan kimia sebelum gempa bumi dan prekursor makro, yang terdiri dari anomali perilaku hewan sebelum gempa bumi. Respon hewan tersebut dapat teramati dalam bentuk anomali perilaku (Kirschvink, 2000) karena dipengaruhi oleh prekursor mikro berupa anomali proses fisika dan kimia. Laporan tentang respon atau perilaku hewan yang tidak biasa sebelum gempa jumlahnya sangat berlimpah (Freund \& Stolc, 2013).

Pada grafik Gambar 3, prekursor mikro yang sudah dikenal baik oleh sebagian besar mahasiwa adalah gelombang P dan panas bumi. Sebaliknya, prekursor mikro yang paling sedikit dikenali oleh mahasiswa adalah kemunculan gas tanah dan ion positif di udara. Penelusuran lanjut melalui wawancara menginformasikan bahwa mahasiswa mengenal gelombang $\mathrm{P}$ berfungsi sebagai penanda gempa bumi dari perkuliahan Ilmu Pengetahuan Bumi dan Antariksa (IPBA) dan mengenal kemunculan panas bumi yang tidak biasa berdasarkan pengalaman dan informasi anecdotal dalam masyarakat. Sedangkan jenis fenomena fisika kimia lainnya yang berfungsi sebagai penanda atau prekursor diketahui dari artikel-artikel non ilmiah yang tersedia di web atau blog. Dibanding prekursor mikro, prekursor makro jauh lebih dikenal oleh mayoritas mahasiswa seperti yang ditampilkan pada grafik Gambar 4. 
Jurnal Pendidikan Geografi:

Kajian, Teori, dan Praktik dalam Bidang Pendidikan dan Ilmu Geografi

Volume 25, Nomor 2, Jun 2020, Hal 88-101

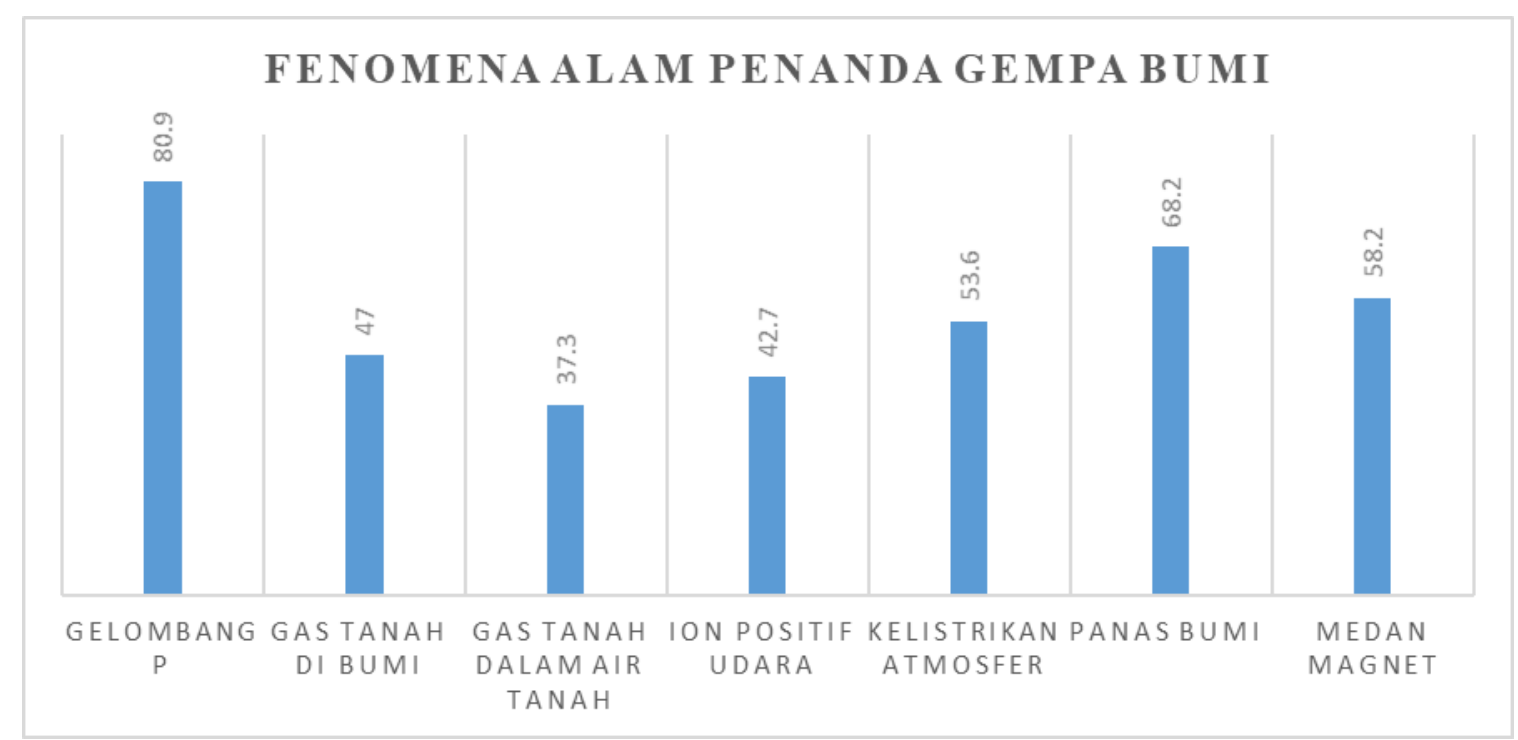

Gambar 3. Persentase mahasiswa yang mengenali prekursor mikro gempa bumi gempa bumi (Sumber: Hasil pengolahan data, 2020)

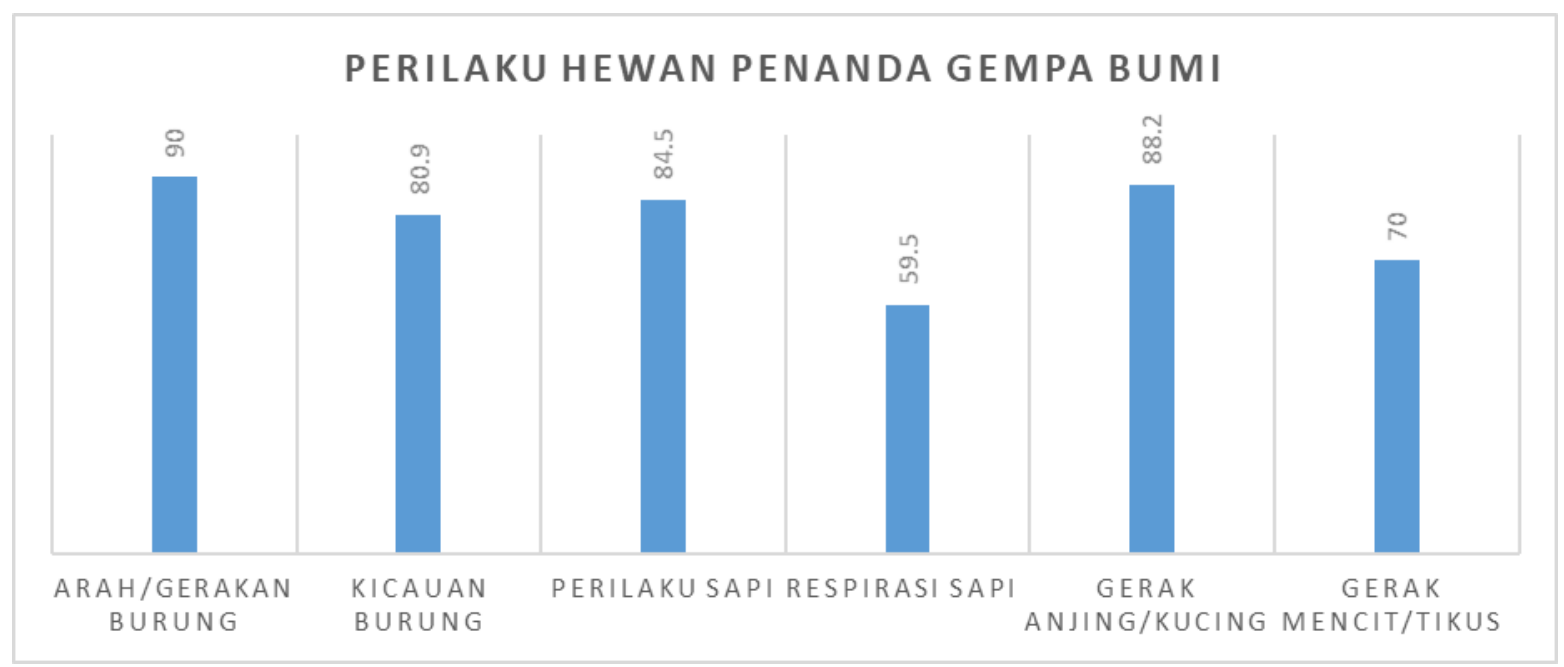

Gambar 4. Persentase mahasiswa yang mengenali prekursor makro gempa bumi (Sumber: Hasil pengolahan data, 2020)

Menurut hasil survei, mahasiswa IPA menyatakan gempa bumi tidak dapat diprediksi, tetapi 50\% diantaranya meyakini bahwa gempa bumi dapat diperkirakan kapan terjadinya berdasarkan fenomena alam dan aktivitas makhluk hidup. Mahasiswa meyakini kemunculan penanda gempa bumi merupakan pengetahuan penting untuk dipelajari lebih lanjut melalui perkuliahan karena sumber informasi/sumber belajar yang tersedia dan akurat sangat terbatas. Mahasiswa mengenal dengan baik bahwa perubahan aktivitas makhluk hidup telah banyak digunakan masyarakat sebagai penanda gempa bumi di lingkungan tinggal mereka. Antara lain perilaku semut dan ular keluar dari sarang, kuda meringkik, tupai berisik, Anjing menggaruk pohon dan suara Anjing dan Kucing yang tidak biasa. Namun, mahasiswa menyatakan tidak mengetahui sama sekali bagaimana mekanisme perubahan perilaku hewan tersebut dapat terjadi. 
Jurnal Pendidikan Geografi:

Kajian, Teori, dan Praktik dalam Bidang Pendidikan dan Ilmu Geografi

Volume 25, Nomor 2, Jun 2020, Hal 88-101

\section{KESIMPULAN}

Tingkat kesiapsiagaan TPPG dan pengetahuan kebumian mahasiswa pendidikan IPA Universitas Negeri Padang termasuk pada kategori sedang, tetapi tingkat pengetahuan penanda gempa bumi termasuk pada kategori sangat rendah. Kesiapsiagaan mahasiswa pendidikan IPA dipengaruhi oleh daerah asal, dimana mahasiswa yang berasal Sumatera Barat memiliki kesiapsiagaan lebih tinggi dibanding mahasiswa yang berasal dari luar Sumatera Barat. Selain itu, mahasiswa yang berasal dari daerah tinggal dataran tinggi memiliki kesispsiagaan yang lebih rendah dibanding mahasiswa yang berasal dari dataran rendah. Kesiapsiagaan TPPG mahasiswa pendidikan IPA tidak dipengaruhi oleh jenis kelamin dan pengetahuan kebumian yang telah dipelajari belum memberikan pengaruh signifikan terhadap kesiapsiagaan TPPG.

\section{DAFTAR PUSTAKA}

Addiarto, W., \& Yunita, R. (2019). Upaya mewujudkan kampus siaga bencana melalui peningkatan kesiapsiagaan mahasiswa keperawatan dengan penerapan metode Tabletop Disaster Exercise. Jurnal Ilmiah Kesehatan Keperawatan, 15(1), 35-39. https://doi.org/10.26753/jikk.v15i1.313.

Adiyoso, W., \& Kanegae, H. (2013). The preliminary study of the role of Islamic teaching in the disaster risk reduction (a qualitative case study of Banda Aceh, Indonesia). Procedia Environmental Sciences, 17, 918-927. https://doi.org/10.1016/ j.proenv.2013.02.110.

Ahadi, S., Puspito, N. T., \& Ibrahim, G. (2015). Anomalous ULF emissions and their possible association with the strong earthquakes in Sumatra, Indonesia, during 20072012. J.Math.Fund.Sci, 47(1), 84-103. https://doi.org/10.5614/ j.math.fund.sci.2015.47.1.7.

Baytiyeh, H., \& Naja, M. K. (2014). Can education reduce middle eastern fatalistic attitude regarding earthquake disasters?. Disaster Prevention and Management, 23 (4), 343-355. https://doi.org/10.1108/DPM-12-2013-0219.

BMKG. (2019). Katalog gempa bumi signifikan dan merusak. Jakarta: Pusat Gempa dan Tsunami Kedeputian Bidang Geofisika.

Bommer, J. J., Crowley, H., \& Pinho, R. (2015). A risk-mitigation approach to the management of induced seismicity. Journal of Seismology, 19(2), 623-646. https:// doi.org/10.1007/s10950-015-9478-z.

Brown, L. M., Haun, J. N., \& Peterson, L. (2014). A proposed disaster literacy model. Disaster Medicine and Public Health Preparedness, 8(3), 267-275. https:// doi.org/10.1017/dmp.2014.43.

Coppola, D. P. (2015). Introduction to International Disaster Management (Edition, T; S. Scott, Ed.). https://doi.org/10.1016/C2009-0-64027-7.

Daneshvar, M. R. M., Tavousi, T., \& Khosravi, M. (2014). Synoptic detection of the short-term atmospheric precursors prior to a major earthquake in the Middle East, North Saravan M 7.8 earthquake, SE Iran. Air Quality, Atmosphere and Health, 7(1), 29-39. https://doi.org/10.1007/s11869-013-0214-y.

Deb, A., Gazi, M., Ghosh, J., Chowdhury, S., \& Barman, C. (2018). Monitoring of soil radon by SSNTD in Eastern India in search of possible earthquake precursor. Journal of Environmental Radioactivity, 184-185(January), 63-70. https://doi.org/10.1016/ j.jenvrad.2018.01.009.

Fadhil, A. (2019). Hubungan pengetahuan, sikap, dan tindakan terhadap kesiapsiagaan bencana alam pada mahasiswa Program Studi Profesi Dokter Fakultas Kedokteran Universitas Andalas (Universitas Andalas). https://doi.org/10.1017/ 
Jurnal Pendidikan Geografi:

Kajian, Teori, dan Praktik dalam Bidang Pendidikan dan Ilmu Geografi

Volume 25, Nomor 2, Jun 2020, Hal 88-101

CBO9781107415324.004.

Fadilah, M., Permanasari, A., Riandi, \& Maryani, E. (2020). The level of disaster literacy of earthquake-experienced students in Mathematics and Science Faculty of State University in Indonesia. Journal of Engineering Science and Technology, Special Is (February), 30-38.

Fauzi, A. R., Hidayati, A., Subagyo, D. O., Sukini, \& Latif, N. (2017). Hubungan tingkat pengetahuan bencana dengan kesiapsiagaan masyarakat di Kecamatan Wonogiri dalam menghadapi bencana gempa bumi. Prosiding Seminar Nasional Geografi UMS 2017, 319-330. Retrieved from http://hdl.handle.net/11617/9039.

Fidani, C., Freund, F., \& Grant, R. (2014). Cows come down from the mountains before the $(\mathrm{Mw}=6.1)$ earthquake Colfiorito in September 1997; a single case study. Animals, 4(2), 292-312. https://doi.org/10.3390/ani4020292.

Freund, F., \& Stolc, V. (2013). Nature of pre-earthquake phenomena and their effects on living organisms. Animals, 3(2), 513-531. https://doi.org/10.3390/ani3020513.

Hariyanto, S., \& Kurniawati. (2019). Pengaruh metode simulasi bencana banjir terhadap tingkat kesiapsiagaan mahasiswa program studi Ilmu Keperawatan FIK UNIPDU Jombang. Journals of Ners Community, 10(1), 67-73.

Havwina, T., Maryani, E., \& Nandi, N. (2017). Pengaruh pengalaman bencana terhadap kesiapsiagaan peserta didik dalam menghadapi ancaman gempa bumi dan tsunami. Jurnal Geografi Gea, 16(2), 124. https://doi.org/10.17509/gea.v16i2.4041.

Hidayati, D., Widyatun, P., Triono, \& Kusumawati. (2011). Panduan mengukur tingkat kesiapsiagaan masyarakat dan komunitas sekolah. Jakarta: LIPI Press.

Ilham, M., Mulyadi, Imran, Syahrul, Mudatsir, \& ZK, J. (2016). Evaluasi partisipasi pendidikan kebencanaan pada mahasiswa Fakultas Kedokteran Universitas Syiah Kuala (setelah mengikuti blok disaster management). Jurnal Kedokteran Syiah Kuala, 16(3), 146-152.

Irsyam, M., Hendriyawan, Natawijaya, D. H., Daryono, M. R., Widiantoro, S., Asrurifak, M., ... Faisal, L. (2017). Development of new seismic hazard maps of Indonesia 2017. Proceedings of the 19th International Conference on Soil Mechanics and Geotechnical Engineering, Seoul 2017, 1525-1528.

Iryanthony, S. B. (2015). Pengembangan modul kesiapsiagaan bencana angin puting beliung untuk mahasiswa Pendidikan Geografi Unnes. Pengembangan Modul Kesiapsiagaan Bencana Angin Puting Beliung Untuk Mahasiswa Pendidikan Geografi Unnes, 12(2), 143-154. https://doi.org/10.15294/jg.v12i2.8002.

Kirschvink, J. L. (2000). Earthquake prediction by animals: evolution and sensory perception. Journal of Seismological Society of America, 90(2), 312-323. https:// doi.org/10.1785/0119980114.

Kohn, S., Eaton, J. L., Feroz, S., Bainbridge, A. A., Hoolachan, J., \& Barnett, D. J. (2012). Personal disaster preparedness: an integrative review of the literature. Disaster Medicine and Public Health Preparedness, 6(3), 217-231. https:// doi.org/10.1001/dmp.2012.47.

Kurniawati, D., \& Suwito, S. (2019). Pengaruh pengetahuan kebencanaan terhadap sikap kesiapsiagaan dalam menghadapi bencana pada mahasiswa Program Studi Pendidikan Geografi Universitas Kanjuruhan Malang. JPIG (Jurnal Pendidikan Dan Ilmu Geografi), 2(2). https://doi.org/10.21067/jpig.v2i2.3507.

LIPI_UNESCO/ISDR. (2006). Kajian kesiapsiagaan masyarakat dalam mengantisipasi bencana gempa bumi \& tsunami. Jakarta: UNESCO Office.

Marlyono, S. G., Pasya, G. K., \& Nandi, N. (2016). Pengaruh literasi informasi bencana terhadap kesiapsiagaan masyarakat dalam menghadapi bencana di Provinsi Jawa 
Barat. Jurnal Pendidikan Geografi, 16(2), 116-123.

Morozova, L. I. (2012). Crustal geodynamic activity: Manifestations in cloud fields. Russian Geology and Geophysics, 53(4), 416-423. https://doi.org/10.1016/ j.rgg.2012.02.014.

Muafiroh, D. F. M., Suroto, S., \& Ekawati, E. (2017). Faktor - faktor yang berhubungan dengan upaya kesiapsiagaan tanggap darurat Keselamatan dan Kesehatan Kerja (K3) di laboratorium kimia Departemen X Fakultas Y Universitas Diponegoro. Jurnal Kesehatan Masyarakat (e-Journal), 5(5), 105-114.

Normadewi, B., \& Arifin. (2012). Analisis pengaruh jenis kelamin dan tingkat pendidikan terhadap persepsi etis mahasiswa Akuntansi dengan love of money sebagai variabel intervening. Universitas Dipoenegoro.

Novarita, A. (2019). Pengurangan risiko bencana pada sikap kesiapsiagaan dalam menghadapi bencana pada mahasiswa Program Studi Pendidikan Geografi Universitas Tadulako. Jurnal Pendidikan Geografi, 7(1), 1-9. https:// doi.org/.1037//0033-2909.I26.1.78.

Oh, Y. H., \& Kim, G. (2015). A radon-thoron isotope pair as a reliable earthquake precursor. Scientific Reports, 5, 220-225. https://doi.org/10.1038/srep13084.

Purborini, S. D., \& Hastari, R. C. (2019). Analisis kemampuan spasial pada bangun ruang sisi datar ditinjau dari perbedaan gender. Jurnal Derivat: Jurnal Matematika dan Pendidikan Matematika, 5(1), 49-58. https://doi.org/10.31316/j.derivat.v5i1.147.

Rachmalia, M. N. S., Hatthakit, U., \& Chaowalit, A. (2011). Tsunami preparedness of people living in affected and non-affected areas: A comparative study in coastal area in Aceh, Indonesia. Australasian Emergency Nursing Journal, 14(1), 17-25. https:// doi.org/10.1016/j.aenj.2010.10.006.

Rafelito, \& Triyatno. (2019). Kesiapsiagaan mahasiswa Universitas Negeri Padang terhadap Bencana Gempa dan Tsunami. Jurnal Kapita Seleksta Geografi, 2(2016), 109-115. https://doi.org/10.24036/ksgeo.v2i1.147.

Rahayu, R. D., \& Wigna, W. (2011). Pengaruh lingkungan keluarga, sekolah dan masyarakat terhadap persepsi gender mahasiswa laki-laki dan perempuan. Sodality: Jurnal Sosiologi Pedesaan, 5(2). https://doi.org/10.22500/sodality.v5i2.5819.

Rizqillah, A. F. (2019). Disaster preparedness: Survey study pada mahasiswa Keperawatan Universitas Harapan Bangsa Purwokerto. Medisains, 16(3), 114. https://doi.org/10.30595/medisains.v16i3.3120.

Sajidah, C. F., Hasmunir, \& Abdi, A. W. (2017). Korelasi nilai mata kuliah Geologi Umum dan Mitigasi Bencana dengan kesiapsiagaan menghadapi bencana gempa dan tsunami pada mahasiswa Program Studi Pendidikan Geografi FKIP Unsyiah. Ilmiah Mahasiswa Pendidikan Geografi FKIP Unsyiah, 2, 12-23. Retrieved from http:// jurnal.unpad.ac.id/mkk/article/view/22742/11878.

Sampurno, P. J., Sari, Y. A., \& Wijaya, A. D. (2015). Integrating STEM (Science, Technology, Engineering, Mathematics) and Disaster (STEM-D) education for building students. International Journal of Learning and Teaching, 1(1), 73-76. https://doi.org/10.13140/RG.2.1.2384.9443.

Saraf, A. K., \& Choudhury, S. (2004). Satellite detects pre-earthquake thermal anomalies associated with past major earthquakes. Proceedings of Map Asia, 40.

Saraf, A. K., \& Choudhury, S. (2005). Thermal remote sensing technique in the study of pre-earthquake thermal anomalies. J. Ind. Geophys. Union, 9(3), 197-207. Retrieved from http://igu.in/9-3/5arun.pdf.

Song, R., Hattori, K., Zhang, X., \& Sanaka, S. (2020). Seismic-ionospheric effects prior to four earthquakes in Indonesia detected by the China seismo-electromagnetic 
Jurnal Pendidikan Geografi:

Kajian, Teori, dan Praktik dalam Bidang Pendidikan dan Ilmu Geografi

Volume 25, Nomor 2, Jun 2020, Hal 88-101

satellite. Journal of Atmospheric and Solar-Terrestrial Physics, 205(April), 105291. https://doi.org/10.1016/j.jastp.2020.105291.

Sunardi, B., Muslim, B., \& Pakpahan, S. (2016). Anomali Total Electron Content (TEC) sebelum gempa bumi kuat di Indonesia tahun 2014. Seminar Nasional Jurusan FISIKA FMIPA UNESA 2015, (November2015).

Tjandra, K. (2018). Indonesia rawan bencana geologi dalam empat bencana geologi yang paling mematikan. Kota Yogyakarta, Indonesia: UGM Press.

Yamauchi, H., Uchiyama, H., Ohtani, N., \& Ohta, M. (2014). Unusual animal behavior preceding the 2011 earthquake off the Pacific Coast of Tohoku, Japan: A way to predict the approach of large earthquakes. Animals, 4(2), 131-145. https:// doi.org/10.3390/ani4020131.

Yokoi, S., Ikeya, M., Yagi, T., \& Nagai, K. (2003). Brief communication mouse circadian rhythm before the Kobe earthquake in 1995. Bioelectromagnetics, 291 (December 2002), 1995-1997. https://doi.org/10.1002/bem.10108.

Zollinger, S. A., \& Brumm, H. (2015). Why birds sing loud songs and why they sometimes don't. Animal Behaviour, 105, 289-295. https://doi.org/10.1016/ j.anbehav.2015.03.030. 